\title{
Zinc Supplementation Effect in MDA and MMP8 During LPS- Induced Sepsis and Its Benefits to Reduce The Child Mortality in Hospital Practice
}

\author{
Martono T. Utomo ${ }^{1}$, Subijanto M. Sudarmo ${ }^{1}$, Ketut Sudiana ${ }^{2}$ \\ ${ }^{1}$ Department of Child Health, Faculty of Medicine, Universitas Airlangga, Surabaya, Indonesia \\ ${ }^{2}$ Department of Pathology Anatomy, Faculty of Medicine, Universitas Airlangga, Surabaya, Indonesia \\ Corresponding author : mrmartono73@gmail.com
}

\begin{abstract}
Background: Severe sepsis increases pro-inflammatory cytokines, causing systemic translocation to the commensal bacteria. A study in Southeast Asia involving 13 public hospitals in 3 countries, including Indonesia, found that sepsis mortality in children was $2 \%$ and a $28 \%$ incidence of severe sepsis. Low plasma zinc levels were found in severe and critically septic patients in children and adults.

Objective: This study aims to explain the mechanism of sepsis improvement after zinc administration through MDA and MMP8 during LPS-induced sepsis in rodents.

Material and Methods: We divided samples of 40 rats into four groups of Control, LPS, LPS-Zinc, and Zinc. Blood sampling in 2-hour after LPS or placebo administration to measure zinc level. Zinc was administered in LPS-Zinc and Zinc group and placebo in two other groups. Blood sampling in 8, 24, and 72 hours to measure MDA and MMP-8 by sandwich-ELISA method. Statistical analysis was carried out with one-way ANOVA, Kruskal Wallis, Mann-Whitney, Paired t-tests, Wilcoxon Signed Rank Test, and path analysis.

Results: Oral administration of zinc decreased the expression of monocyte MDA and MMP-8. The mechanism of zinc in the repair of sepsis through inhibition of MDA and MMP-8. Zinc supplementation can possibly reduce the the risk of child mortality in sepsis case.

Conclusion: Administration of zinc in sepsis improves the condition of sepsis by decreasing pro-inflammatory cytokine and increasing anti-inflammatory cytokine
\end{abstract}

Keywords: Zinc ; sepsis ; MDA ; MMP-8 ; Child mortality

\section{Introduction}

In-hospital mortality due to sepsis is $15 \%$ and severe sepsis is $26 \%$ in adults has an incidence rate of 437 cases of sepsis and 270 cases of severe sepsis per 100,000 people per year. It is estimated that there are 31.5 million cases of sepsis globally and 19.4 million severe sepsis with potential mortality of 5.3 million. ${ }^{1}$ Research at Dr. Soetomo Hospital showed mortality due to sepsis $16.7 \%$, severe sepsis $27.08 \%$, and septic shock $14.58 \%{ }^{2}$ Low plasma zinc levels are found in children and adults patients with severe and critical sepsis. ${ }^{3-5}$ We can conclude that low zinc levels in patients with severe and critical sepsis are still a problem.

There are two phases of immune responses in sepsis, a hyperinflammatory phase characterized by the predominance of proinflammatory cytokines and a hypo-inflammation phase in the form of an uncontrolled anti-inflammatory response. In sepsis, vascular endothelial damage occurs due to ROS and MMP- 8 produced by neutrophils. ${ }^{6-8}$ Damage due to ROS activity is characterized by an increase in MDA (malondialdehyde) which is the end product of oxidative stress in phospholipid membranes. High levels of MDA and MMP-8 are associated with septic mortality. ${ }^{9,10}$ Improvement of sepsis symptoms after zinc administration was found in the study of Bhatnagar, 2012 which gave zinc $10 \mathrm{mg}$ /day as adjuvant therapy in neonatal sepsis. ${ }^{11}$ 
Zinc reduces oxidative stress and ROS production because zinc functions as a scavenger enzyme. ${ }^{12}$ Zinc also reduces levels of CRP, lipid peroxidase, and proinflammatory cytokines. ${ }^{13}$ The increase in TGF- inhibits the expression of MMP-8 in cell culture preparations ${ }^{14}$, so that zinc can indirectly reduce MMP-8. Malondialdehyde (MDA) is an end product during oxidative stress events on membrane phospholipids. A high MDA is found in sepsis and is associated with death at 30 days. ${ }^{10}$ Serum MMP-8 is also elevated in severe sepsis. ${ }^{15}$ Neonatal sepsis is a major problem that requires special attention in the field of neonatal care because of its high prevalence and mortality. The diagnosis and management of neonatal sepsis are often late and various risk factors aggravate the condition. This could be because of in zinc deficiency that leads to poor prognoses. ${ }^{16}$

\section{Methods}

\subsection{Preparation of animal study}

This was an experimental study with a completely randomized design. Ethical clearance was given, number 700-KEP-UB. We use healthy male Sprague-Dawley rats (Rattus norvegicus) aged 10-12 weeks and excluded if there were congenital abnormalities at birth. The rats were acclimatized for two weeks at the Institute of Biosciences, Brawijaya University before being used. Feeding standard pellets and drinking water ad libitum and the husks are changed every two days. We had done and published similar studies in zinc and sepsis. ${ }^{17}$

\subsection{Serum Zinc Levels}

The zinc sulfate solution was given by adding $9 \mathrm{~mL}$ of aquadest to $1 \mathrm{~mL}$ of zinc sulfate drop $(10 \mathrm{mg} / \mathrm{mL})$, the dose was $4.65 \mathrm{mg} / \mathrm{kg}$ BW for rats. Stimulation of LPS E. Coli serotype O111: B4 at a dose of $10 \mathrm{mg} / \mathrm{kg}$ body weight of rats was administered intravenously to the group given LPS. A sampling of rat blood was taken from the tail at the $2 \mathrm{nd}$ hour as much as $2 \mathrm{~mL}$ for zinc examination and another $2,5 \mathrm{ml}$ blood samples at the $8^{\text {th }}$ and $24^{\text {th }}$ hours for ELISA and ICC tests, while at $72^{\text {nd }}$ hour we collect blood samples from the rat aorta. Then divided into samples with EDTA (centrifuged at $6,000 \mathrm{G}$ for 10 minutes at $25^{\circ} \mathrm{C}$ within 30 minutes after being collected and stored in a $-20^{\circ} \mathrm{C}$ refrigerator) and without EDTA (stored in a $-20^{\circ} \mathrm{C}$ refrigerator). Blood samples without EDTA were The examination of blood zinc levels using the AAS method begins with making a standard zinc solution of $1000 \mathrm{mg}$ zinc/liter by diluting $10 \mathrm{~mL}$ of nitric acid to $50 \mathrm{~mL}$ by adding $1,000 \mathrm{~g}$ of zinc, diluting it again to $100 \mathrm{ml}$. As much as $1 \mathrm{~mL}$ of standard zinc mixed with a 5/95 to $100 \mathrm{~mL}$ glycerol water solution, shaken 16 times, then 1, 2, 3, $4 \mathrm{~mL}$ were taken into $100 \mathrm{~mL}$ volume flask and added with a 5/95 glycerol/water solution. Solutions $(0.1,0.2,0.3$, and $0.4 \mathrm{mg}$ zinc per liter) were associated with plasma zinc concentrations of $500,1,000,1,500$, and $2,000 \mathrm{~g}$ of zinc per liter. We use $1.2 \mathrm{~mL}$ of blood with a drop of sodium citrate, then centrifuged $900 \mathrm{G}$ for 20 minutes. Take $0.5 \mathrm{~mL}$ of plasma and add $2 \mathrm{~mL}$ of de-ionized water mixed for 30 seconds, using spectrophotometry to read the results by comparing with standard zinc solutions. ${ }^{18}$

\subsection{Cytokine Analysis}

Measurement of MDA and MMP-8 levels was performed by Sandwich-ELISA method using universal MDA ELISA Kit (7,813-500 ng / mL) 96T EU 2577, and Rat MMP-8 ELISA Kit (78,125-5000 pg / mL) 96 T ER 1166.

\subsection{Assay Analysis}

Before adding the reagent to the well, the TMB substrate was placed at $37 \mathrm{oC}$ for 30 minutes. Standard wells, test and control samples, and stews were pre-coated with anti-MDA, and MMP-8 antibodies. The plates were washed twice before adding standards, samples, and controls. Aliquot $0.1 \mathrm{~mL}$ of $1000 \mathrm{pg} / \mathrm{mL}, 500 \mathrm{pg} /$ $\mathrm{mL}, 250 \mathrm{pg} / \mathrm{mL}, 125 \mathrm{pg} / \mathrm{mL}, 62.5 \mathrm{pg} / \mathrm{mL}, 31.25 \mathrm{pg} / \mathrm{mL}, 15,625 \mathrm{pg} / \mathrm{mL}$ standard solution MDA, and MMP-8 into the standard well. A $0.1 \mathrm{~mL}$ standard dilution buffer sample is added to the control well and a 0.1 $\mathrm{mL}$ serum sample is added to the test sample well. Close the plate and incubate at $37^{\circ} \mathrm{C}$ for 90 minutes. Then 
the plates were washed twice with washing buffer. As much as $0.1 \mathrm{~mL}$ Biotin-labeled antibody solution was added to wells (standard, test, and control samples). Incubated at $37^{\circ} \mathrm{C}$ for 60 minutes then washed 3 times with washing buffer and left in the well for 1 minute. The $0.1 \mathrm{~mL} \mathrm{SABC}$ solution was added then closed and incubated at $37^{\circ} \mathrm{C}$ for 30 minutes. The plates are washed 5 times with washing buffer and left for $1-2$ minutes. $90 \mu \mathrm{L}$ TMB substrate was added and incubated at $37^{\circ} \mathrm{C}$ in a dark room for $15-30$ minutes. The reaction was stopped by adding a $50 \mu \mathrm{L}$ stopping solution. The O.D absorbance was read using a microplate reader at 450 $\mathrm{nm}$ and the color changed to yellow.

\subsection{Statistical Analysis}

We analyzed zinc levels, MDA, and MMP-8 with descriptive analysis. One-way ANOVA was used to analyze the difference between mean and standard deviation (SD) levels of zinc, MDA and MMP-8 by first doing a normality test of all the dependent variables on all group. Comparison of group data at $8^{\text {th }}, 24^{\text {th }}$, and $72^{\text {nd }}$ hour measurements were performed with Same Subject ANOVA analysis if the distribution was normal and Friedman's ANOVA if the distribution wasn't normal. The zinc action mechanism was analyzed using Path Analysis $(\alpha=0.05)$.

\section{Result}

This research was conducted from March 2017 to December 2017 using white male rats (Rattus norvegicus) Sprague-Dawley strain. We divided forty rats into four groups of ten each: the control group (C), the LPS group (L), the LPS-Zinc group (LZ), and the Zinc group (Z). Table 1 shows that there's no difference in body weight between groups before the treatment is given ( $p>0.05$ ). The LPS and LPS-Zinc groups received intravenous administration of LPS E. Coli. The control and zinc groups with aqua dest placebo. Blood was collected $(2.5 \mathrm{~mL})$ at the $2^{\text {nd }}$ hour on five rats in each group to measure zinc levels. The aqua placebo was given to the control group and the LPS group at the $2^{\text {nd }}, 24^{\text {th }}$, and $48^{\text {th }}$ hours. We give zinc $4.65 \mathrm{mg} / \mathrm{kg} \mathrm{BW}$ in the form of zinc sulfate solution for $10 \mathrm{mg} / \mathrm{mL}$ diluted to $1 \mathrm{mg} / \mathrm{mL}$ in the LPS-Zinc group and the zinc group at $2^{\text {nd }}, 24^{\text {th }}$, and $48^{\text {th }}$ hours. Two death occurred in the LPS group at the $8^{\text {th }}$ and $24^{\text {th }}$ hours.

Table 1. Mean Rats Body Weight in four groups

\begin{tabular}{cccccc}
\hline \multirow{2}{*}{ Group } & $\mathrm{n}$ & \multicolumn{4}{c}{ Body Weight $(\mathrm{g})$} \\
& & Mean & Minimum & Maximum & $\mathrm{P}$ \\
\hline Control & 5 & 221,40 & 213 & 229 & \\
LPS & 5 & 240,80 & 225 & 253 & 0,336 \\
LPS-Zinc & 5 & 226,60 & 208 & 256 & \\
Zinc & 5 & 232,80 & 202 & 263 & \\
\hline
\end{tabular}




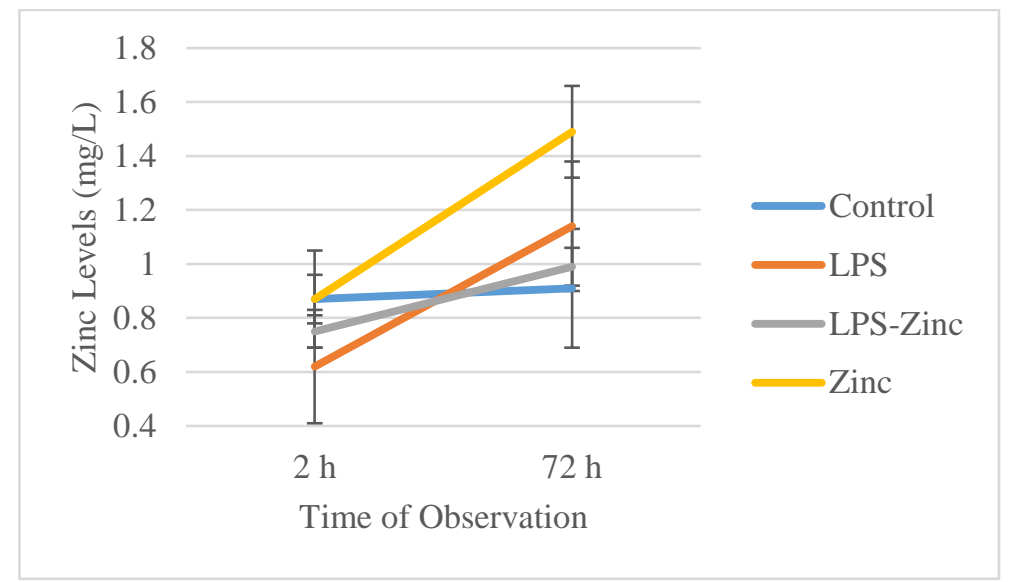

Fig 1. Comparison of zinc levels at $2 \mathrm{~h}$ and $72 \mathrm{~h}$ in 4 groups

After two hours of administration of LPS E. Coli $10 \mathrm{mg} / \mathrm{kg} \mathrm{BW}$ intravenously, we found zinc deficiency (normal zinc levels were $84-159 \mu \mathrm{g} / \mathrm{dL}$ ) in LPS and LPS-Zinc groups. There were differences between the Zinc group and the other three groups (Control, LPS, and LPS-Zinc) after $72^{\text {nd }}$ hours. The difference in zinc levels at the $2^{\text {nd }}$ and $72^{\text {nd }}$ hours shows that three days of zinc administration can increase zinc levels (Table 2 and Figure 1). MDA levels in the LPS group were higher than the other three groups at 8, 24, and 72 hours and there was an increase in MDA levels from 8 to 72 hours showing a continuous process of ROS tissue-damaging process. The MDA levels in the control group were lower than the other, but there was an increase at the $24^{\text {th }}$ and $72^{\text {nd }}$ hours when compared to the 8th hour. We can see that ROS tissue-damaging process can still happen under normal conditions, but not as big as in sepsis. Higher MDA in the zinc group than the control group indicated that zinc administration under normal conditions can increase MDA levels (Table 2 and Figure 2).

Table 2. Serum zinc levels at $2 \mathrm{~h}$ and $72 \mathrm{~h}$ after LPS E. Coli administration

\begin{tabular}{|c|c|c|c|c|}
\hline \multirow{2}{*}{ Group } & \multirow{2}{*}{$\mathrm{n}$} & \multicolumn{2}{|c|}{ Zinc Levels (mg/L) } & \multirow{2}{*}{$\mathrm{P}$} \\
\hline & & $2 \mathrm{~h}$ & $72 \mathrm{~h}$ & \\
\hline Control & 5 & $\begin{array}{l}0,87 \pm 0,09 \\
(0,75-0,97)\end{array}$ & $\begin{array}{c}0,91 \pm 0,22^{\mathrm{a}} \\
(0,57-1,19)\end{array}$ & 0,670 \\
\hline LPS & 5 & $\begin{array}{l}0,62 \pm 0,21 \\
(0,42-0,97)\end{array}$ & $\begin{array}{l}1,14 \pm 0,24^{\mathrm{a}} \\
(0,94-1,54)\end{array}$ & $0,039 * *$ \\
\hline $\begin{array}{l}\text { LPS- } \\
\text { Zinc }\end{array}$ & 5 & $\begin{array}{l}0,75 \pm 0,06 \\
(0,71-0,86)\end{array}$ & $\begin{array}{c}0,99 \pm 0,07^{\mathrm{a}} \\
(0,94-1,11)\end{array}$ & $0,043 * *$ \\
\hline $\begin{array}{l}\text { Zinc } \\
\qquad p\end{array}$ & 5 & $\begin{array}{c}0,87 \pm 0,18 \\
(0,62-1,12) \\
0,073\end{array}$ & $\begin{array}{c}1,49 \pm 0,17^{\mathrm{b}} \\
(1,33-1,74) \\
0,001^{*}\end{array}$ & $0,001 * *$ \\
\hline
\end{tabular}




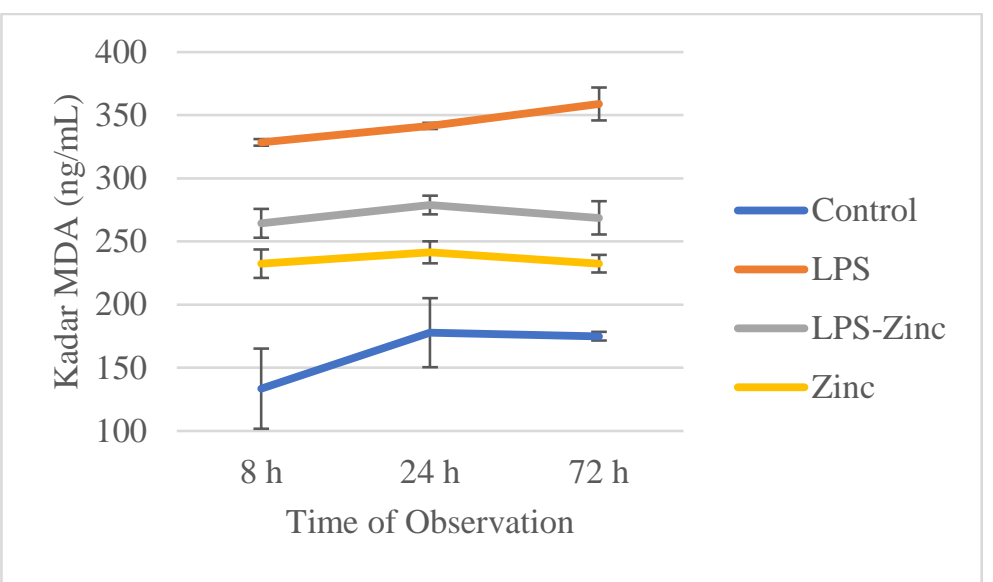

Figure 2. Comparison of MDA serum levels at $8 \mathrm{~h}, 24 \mathrm{~h}$ and $72 \mathrm{~h}$ in 4 groups

Table 3 shows that MMP-8 levels in the LPS group were higher than the other three groups at the $8^{\text {th }}, 24^{\text {th }}$, and $72^{\text {nd }}$ hours and there was an increase from the $8^{\text {th }}$ hour to the $72^{\text {nd }}$ hour. Lower MMP- 8 levels in the zinc group than the control group at 8,24 , and 72 hours indicating that under normal conditions zinc could inhibit MMP-8. There was an increase in MMP-8 levels in the Control group at 8, 24, and 72 hours proved that MMP8 was also involved in the tissue degradation process (figure 3). Zinc's endothelial damage prevention can be seen from the lower levels of MDA and MMP-8 in the LPS-Zinc group compared to the LPS group, starting from the $8^{\text {th }}$ hour to the $72^{\text {nd }}$ hour. Zinc administration under normal conditions could increase MDA levels compared to controls, but still lower than the LPS-Zinc group, but zinc administration under normal conditions decreased MMP-8 levels compared to controls.

Tabel 3. Serum MMP- 8 levels at $8 \mathrm{~h}, 24 \mathrm{~h}$, and $72 \mathrm{~h}$ in four groups

\begin{tabular}{|c|c|c|c|c|c|}
\hline \multirow{2}{*}{ Group } & \multirow{2}{*}{$\mathrm{n}$} & \multicolumn{3}{|c|}{ Serum MMP-8 levels (pg/L) } & \multirow{2}{*}{$\mathrm{p}$} \\
\hline & & $8 \mathrm{~h}$ & $24 \mathrm{~h}$ & $72 \mathrm{~h}$ & \\
\hline Control & 5 & $\begin{array}{c}310,83 \pm 2,95^{\mathrm{b}} \\
(307,27-315,35)\end{array}$ & $\begin{array}{l}323,04 \pm 1,30^{b} \\
(321,12-324,58)\end{array}$ & $\begin{array}{c}321,65 \pm 2,82^{b} \\
(316,93-324,19)\end{array}$ & $0,000 * *$ \\
\hline LPS & 5 & $\begin{array}{l}571,69 \pm 11,93^{d} \\
(557,27-584,96)\end{array}$ & $\begin{array}{c}584,29 \pm 6,27^{\mathrm{d}} \\
(575,35-590,73)\end{array}$ & $\begin{array}{l}656,69 \pm 22,93^{d} \\
(629,58-692,65)\end{array}$ & $0,000 * *$ \\
\hline LPS-Zinc & 5 & $\begin{array}{c}507,17 \pm 2,28^{c} \\
(503,42-509,58)\end{array}$ & $\begin{array}{c}515,73 \pm 3,06^{c} \\
(511,50-519,19)\end{array}$ & $\begin{array}{c}526,21 \pm 0,57^{\mathrm{c}} \\
(525,35-526,89)\end{array}$ & $0,000 * *$ \\
\hline Zinc & 5 & $\begin{array}{c}288,73 \pm 1,52^{\mathrm{a}} \\
(286,50-290,35)\end{array}$ & $\begin{array}{c}292,81 \pm 2,08^{a} \\
(290,35-295,72)\end{array}$ & $\begin{array}{c}299,19 \pm 3,31^{\mathrm{a}} \\
(294,58-303,04)\end{array}$ & $0,001 * *$ \\
\hline $\mathbf{p}$ & & $0,000 *$ & $0,000 *$ & $0,000^{*}$ & \\
\hline
\end{tabular}




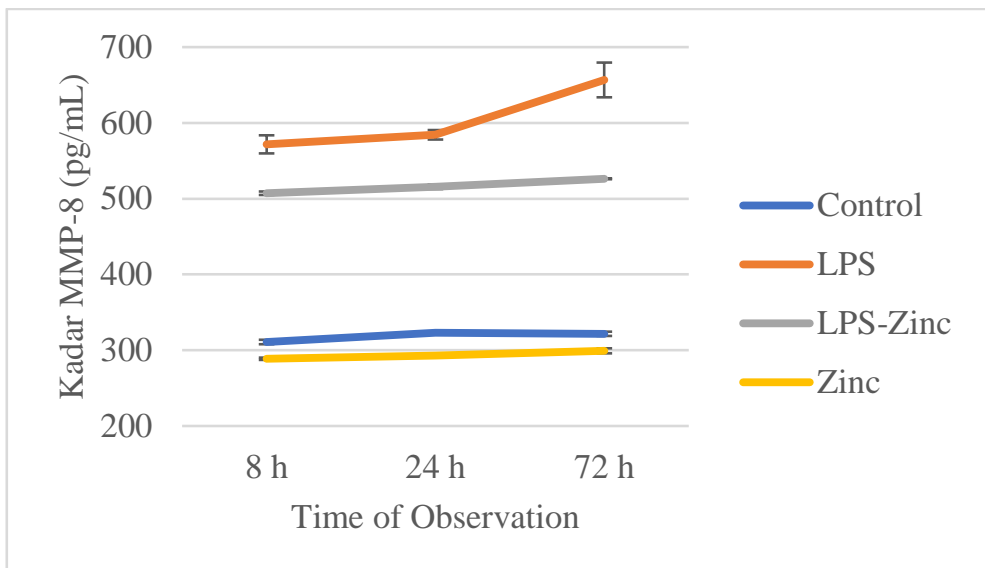

Figure 3. Comparison of MMP-8 serum levels at $8 \mathrm{~h}, 24 \mathrm{~h}$ and $72 \mathrm{~h}$ in 4 groups

\section{Discussion}

This study aims to reveal the mechanism of action of zinc in sepsis-induced by LPS E. Coli. Tissue damage was indicated by MDA and MMP-8. We compared the LPS group with the control group to see the changes that occurred in sepsis compared to normal conditions, the LPS-Zinc group to the LPS group to see the effect of zinc administration on sepsis. The zinc group was compared to the control group to see the effect of zinc administration under normal conditions. Intravenous LPS E. Coli was successfully used as inflammatory sepsis agents in experimental animal models, shown by higher MDA and MMP-8 in the group receiving LPS E. Coli compare to controls. High levels of MDA and MMP-8 are associated with septic mortality. ${ }^{10,15}$

LPS E. Coli has been used in several studies as a model for sepsis in experimental animals, administered intraperitoneal, intravenous, and CLP. (Caecal Ligation and Puncture) ${ }^{19,20}$ The dose of LPS used in this study was $10 \mathrm{mg} / \mathrm{kg}$ BW intravenously as used in previous studies. ${ }^{17}$ The decrease in zinc levels 2 hours after LPS administration in the LPS and LPS-Zinc groups in this study was not as substantial as the decrease in plasma zinc levels in septic and critical conditions in previous studies (45-48 g/dL). ${ }^{3-5}$ In this study, the average zinc level in the LPS group was $0.62 \mathrm{mg} / \mathrm{L}$ or $62 \mathrm{~g} / \mathrm{dL}$ and $0.75 \mathrm{mg} / \mathrm{L}$ or $75 \mathrm{~g} / \mathrm{dL}$ in the LPS-Zinc group, which was included as zinc deficiency (normal values for zinc levels $84-159 \mathrm{~g} / \mathrm{dL}$ ), ${ }^{21}$ while in the control and zinc groups, zinc levels were normal. It could be that the intravenous LPS E. Coli that triggered the sepsis symptoms in this study didn't cause severe sepsis.

There is an increase in ROS production in sepsis that is shown by an increase in MDA. The LPS group zinc levels increase at 72 hours point out zinc function as a scavenger enzyme to neutralize the ROS formed. MDA is the result of the breakdown of lipid peroxide formed from the reaction of arachidonic acid with ROS. Consistently high serum MDA levels are associated with mortality in sepsis. ${ }^{10}$ LPS exposure can increase MDA in several organs such as mouse brain tissue. ${ }^{22}$ The dose of LPS that can cause an increase in MDA is $10 \mathrm{mg} / \mathrm{kg}$ while lower doses of $0.5,1$, and $2 \mathrm{mg} / \mathrm{kg}$ can't. ${ }^{23}$ The administration of zinc in this study could reduce MDA levels in the LPS-zinc group when compared to the LPS group. Administration of zinc as a scavenger enzyme reduces MDA so that tissue damage due to ROS can be prevented. Research on the effect of zinc administration on healthy people for eight weeks comparing pre and post zinc MDA levels found a significant decrease in MDA. ${ }^{24}$

MMP-8 is a matrix tissue degradation enzyme released by leukocytes during inflammation. ${ }^{25}$ In this study, there was an increase in MMP-8 in the experimental group of animals injected with intravenous LPS E. Coli. MMP formation is induced by LPS indirectly through the cytokines IL1 and TNF- $\alpha .{ }^{25}$ Elevated MMP- 8 occurs 
in septic shock in pediatric patients and is associated with decreased life expectancy and increased organ failure. ${ }^{26}$ The administration of zinc to the group injected with LPS E. Coli resulted in a lower reduction in blood MMP-8 levels than the group injected with LPS E. Coli.

Zinc levels in the LPS-Zinc group at 72 hours were increased, even not as high as the LPS group, manifest improved sepsis and decreased ROS production, indicated by low MDA levels. Zinc wasn't required much as a scavenger enzyme for the ROS production had decreased. The AAS method examination reflects total zinc levels in serum and can't distinguish free and albumin-bound zinc levels. The total zinc levels in the serum consist of free zinc bound to albumin. Serum zinc levels are $0.1 \%$ of the zinc content in the body and $98 \%$ of zinc bound to serum proteins resulting in no interaction with immune cells and tissues. There is a decrease in total serum zinc, free zinc, and zinc-binding capacity of albumin in sepsis. Zinc addition in sepsis causes an increase in free zinc levels thus inversely proportional to total albumin levels. ${ }^{27} \mathrm{~A}$ new finding from this study is that zinc administration in sepsis experimental animals can reduce MDA and MMP- 8 cytokines.

Serum zinc level is associated with the prognosis of early onset neonatal sepsis, where serum zinc levels $<75 \mu \mathrm{g} / \mathrm{dL}$ are signficantly predictive of a worse prognosis than serum zinc levels $>75 \mu \mathrm{g} / \mathrm{dL} .{ }^{17} \mathrm{~A}$ meta-analysis on RCTs done by Rouhani, Rezaei and Saneei revealed that zinc supplementation in under 5-year children has significantly reduced the risk of all-cause mortality. ${ }^{28}$ Preventive zinc also improves the growth of children in developing countries and reduces total deaths in 1-to 4 -year-old children by $18 \% .{ }^{29}$ Zinc supplementation in neonates with sepsis improves the neurological status at one month of age although the mortality reduction was not statistically significant. ${ }^{30}$

\section{Conclusion}

Oral administration of zinc decreased the expression of monocyte MDA and MMP-8. The mechanism of zinc in the repair of sepsis through inhibition of MDA and MMP-8. Zinc supplementation can possibly reduce the the risk of child mortality in sepsis case.

\section{Acknowledgements}

We thank our colleagues from Bioscience Institute Brawijaya University who provided insight and expertise that greatly assisted the research, although they may not agree with all of the interpretations/ conclusions of this paper.

\section{References}

1. Fleischmann C, Scherag A, Adhikari NKJ, Hartog CS, Tsaganos T, Schlattmann P, et al. Assessment of Global Incidence and Mortality of Hospital-treated Sepsis. Current Estimates and Limitations. American Journal of Respiratory and Critical Care Medicine $2016 ; 193$. https://doi.org/10.1164/rccm.201504-07810C.

2. Danny Irawan, Hamidah, Purwati, Triyono EA, Bramantono, Arfianto V, et al. Profil Penderita Sepsis Akibat Bakteri Penghasil ESBL. Journal of Internal Medicine 2012;13:63-8.

3. Hoeger J, Simon T-P, Beeker T, Marx G, Haase H, Schuerholz T. Persistent low serum zinc is associated with recurrent sepsis in critically ill patients - A pilot study. PLOS ONE 2017;12. https://doi.org/10.1371/journal.pone.0176069.

4. Alker W, Haase H. Zinc and Sepsis. Nutrients 2018;10. https://doi.org/10.3390/nu10080976.

5. Helmy TA, Beshey BN. Correlation between serum zinc and mortality in septic patients. International Journal of Advanced Research 2016;4. https://doi.org/10.21474/IJAR01/240

6. ZHAO Q-T, GUO Q-M, WANG P, WANG Q. Salvianic acid A inhibits lipopolysaccharide-induced apoptosis through regulating glutathione peroxidase activity and malondialdehyde level in vascular endothelial cells. Chinese Journal of Natural Medicines $2012 ; 10$. https://doi.org/10.1016/S1875-5364(12)60012-0.

7. Guo J, Wang L, Wang L, Qian S, Zhang D, Fang J, et al. Berberine Protects Human Umbilical Vein Endothelial Cells against LPSInduced Apoptosis by Blocking JNK-Mediated Signaling. Evidence-Based Complementary and Alternative Medicine $2016 ; 2016$. https://doi.org/10.1155/2016/6983956.

8. Ince C, Mayeux PR, Nguyen T, Gomez H, Kellum JA, Ospina-Tascón GA, et al. The Endothelium in Sepsis. Shock $2016 ; 45$. 
https://doi.org/10.1097/SHK.0000000000000473.

9. Lauhio A, Hästbacka J, Pettilä V, Tervahartiala T, Karlsson S, Varpula T, et al. Serum MMP-8, -9 and TIMP-1 in sepsis: High serum levels of MMP-8 and TIMP-1 are associated with fatal outcome in a multicentre, prospective cohort study. Hypothetical impact of tetracyclines. Pharmacological Research 2011;64. https://doi.org/10.1016/j.phrs.2011.06.019.

10. Lorente L, Martín MM, Abreu-González P, Domínguez-Rodriguez A, Labarta L, Díaz C, et al. Sustained high serum malondialdehyde levels are associated with severity and mortality in septic patients. Critical Care 2013;17. https://doi.org/10.1186/cc13155.

11. Bhatnagar S, Wadhwa N, Aneja S, Lodha R, Kabra SK, Natchu UCM, et al. Zinc as adjunct treatment in infants aged between 7 and 120 days with probable serious bacterial infection: a randomised, double-blind, placebo-controlled trial. The Lancet 2012;379. https://doi.org/10.1016/S0140-6736(12)60477-2.

12. Powell SR. The Antioxidant Properties of Zinc. The Journal of Nutrition 2000;130. https://doi.org/10.1093/jn/130.5.1447S.

13. Bao B, Prasad AS, Beck FW, Fitzgerald JT, Snell D, Bao GW, et al. Zinc decreases C-reactive protein, lipid peroxidation, and inflammatory cytokines in elderly subjects: a potential implication of zinc as an atheroprotective agent. The American Journal of Clinical Nutrition 2010;91. https://doi.org/10.3945/ajcn.2009.28836.

14. Moilanen M, Pirilä E, Grénman R, Sorsa T, Salo T. Expression and regulation of collagenase-2 (MMP-8) in head and neck squamous cell carcinomas. The Journal of Pathology 2002;197. https://doi.org/10.1002/path.1078.

15. Gaddnas FP, Sutinen MM, Koskela M, Tervahartiala T, Sorsa T, Salo TA, et al. Matrix- metalloproteinase $-2,-8$ and -9 in serum and skin blister fluid in patients with severe sepsis. Critical Care 2010;14. https://doi.org/10.1186/cc8938.

16. Adnan C, Artana I, Suarta K, Sidiartha I, Gustawan I, Yantie N. Serum zinc level and prognosis of neonatal sepsis. 2021. http://dx.doi.org/10.14238/pi60.2.2020.37-42

17. Martono Tri Utomo, Subijanto M. Sudarmo, Ketut Sudiana. Zinc Supplementation in Cytokine Regulation During LPS-induced Sepsis in Rodent. Journal of International Dental and Medical Research 2020;3:46-50.

18. Smith JC, Butrimovitz GP, Purdy WC. Direct measurement of zinc in plasma by atomic absorption spectroscopy. Clinical Chemistry 1979;25. https://doi.org/10.1093/clinchem/25.8.1487.

19. Lewis AJ, Seymour CW, Rosengart MR. Current Murine Models of Sepsis. Surgical Infections 2016;17. https://doi.org/10.1089/sur.2016.021.

20. Hardiono. Efek immunomodulasi polysaccharidepeptide (PSP) dari ekstraksi Mycelium ganoderma lucidum terhadap apoptosis limfosit, hubungannya dengn kadar TNF-alpha, IL-10, HMGB1, Hsp 90 dan ROS (Studi eksperimental endotoksemia pada tikus Sprague Dawley jantan). 2016

21. Yanagisawa H. Zinc Deficiency and Clinical Practice -Validity of Zinc Preparations-. Yakugaku Zasshi 2008;128. https://doi.org/10.1248/yakushi.128.333.

22. Swarnkar S, Tyagi E, Agrawal R, Singh MP, Nath C. A comparative study on oxidative stress induced by LPS and rotenone in homogenates of rat brain regions. Environmental Toxicology and Pharmacology 2009;27. https://doi.org/10.1016/j.etap.2008.10.003.

23. Requintina PJ, Oxenkrug GF. Differential Effects of Lipopolysaccharide on Lipid Peroxidation in F344N, SHR Rats and BALB/c Mice, and Protection of Melatonin and NAS against Its Toxicity. Annals of the New York Academy of Sciences 2003;993. https://doi.org/10.1111/j.1749-6632.2003.tb07540.x

24. Prasad AS, Bao B, Beck FWJ, Kucuk O, Sarkar FH. Antioxidant effect of zinc in humans. Free Radical Biology and Medicine 2004;37. https://doi.org/10.1016/j.freeradbiomed.2004.07.007.

25. Vanlaere I, Libert C. Matrix Metalloproteinases as Drug Targets in Infections Caused by Gram-Negative Bacteria and in Septic Shock. Clinical Microbiology Reviews 2009;22. https://doi.org/10.1128/CMR.00047-08.

26. Solan PD, Dunsmore KE, Denenberg AG, Odoms K, Zingarelli B, Wong HR. A novel role for matrix metalloproteinase-8 in sepsis*. Critical Care Medicine 2012;40. https://doi.org/10.1097/CCM.0b013e318232e404.

27. Hoeger J, Simon T-P, Doemming S, Thiele C, Marx G, Schuerholz T, et al. Alterations in zinc binding capacity, free zinc levels and total serum zinc in a porcine model of sepsis. BioMetals 2015;28. https://doi.org/10.1007/s10534-015-9858-4

28. Rouhani P, Rezaei Kelishadi M, Saneei P. Effect of zinc supplementation on mortality in under 5-year children: a systematic review and meta-analysis of randomized clinical trials. European Journal of Nutrition. 2021. doi: 10.1007/s00394-021-02604-1

29. Black R, Fischer Walker C. Role of Zinc in Child Health and Survival. Meeting Micronutrient Requirements for Health and Development. 2012;70:37-42. https://doi.org/10.1159/000337393

30. Newton B, Bhat B, Dhas B, Mondal N, Gopalakrishna S. Effect of Zinc Supplementation on Early Outcome of Neonatal Sepsis A Randomized Controlled Trial. The Indian Journal of Pediatrics. 2015;83(4):289-293. doi: 10.1007/s12098-015-1939-4 